\title{
Becoming College and Career Ready: Combating The New Digital Divide - A Literature Review
}

\author{
Nelson A. Orta
}

Department of Learning Technologies, University of North Texas, United States.

\begin{abstract}
The availability of technologies for supporting personal, productivity, communications, and business tasks is ubiquitous and expected. Educational systems have a significant responsibility to ensure future generations are skilled to assume job duties involving the pervasive use of digital assets. Schools and higher education institutions, being at the epicenter of preparing the workforce for the adoption of technologies for learning and productivity, are increasingly making significant investments to develop digital skills among students. Given the increased adoption of technologies for instruction in U.S. classrooms, the digital divide as a concept may be shifting from lack of access, to a deeper context referred to understanding how to purposefully utilize technology to develop literacy, support academic growth, conduct research, and enhance productivity. There is evidence of significant skill gaps between students coming from high versus low socio-economic households, therefore, it is imperative to prioritize investments in technologies for learning and robust digital pedagogy practices in schools serving low socio-economic status students. This paper provides an updated definition of the digital divide and the importance of providing effective technology-based pedagogy to students from poverty to prevent skill gaps from becoming a competitive disadvantage as they strive to be successful in college and careers.
\end{abstract}

Keywords: digital divide; digital learning; technology skills. 


\section{Introduction}

The conceptualization of the digital divide based on lack of access to technology assets is a definition that has historically caused confusion (Gunkel, 2003). Dijk (2006) argued that the generally accepted definition of the digital divide as an access issue is laden with assumptions, including, the existence of a defined gap between two groups, the haves and the have-nots, the suggestion that the existing gap is difficult to close, the affirmation that the inequalities are between included and excluded individuals, and finally, that the digital divide itself is static in nature. Gunkel (2003) and Dijk (2006), both argued that it is often mistakenly suggested that access to technology largely narrows the digital divide while being beneficial for the economy. Assumptions and misconceptions notwithstanding, the term digital divide is still relevant for discussion, analysis and research. Gunkel (2003) stated that the term digital divide carries several meanings with important implications including the modes of divide: divide based on access to technology, and divide based on the skillfull use of technology. The new digital divide is decreasingly based on access and increasingly based on expertise in the utilization of devices: the gap in ability to utilize technology for learning, productivity and research purposes. To be clear, the access-based divide is not entirely a concept of the past; according to Rowsell, Morrell, and Alvermann (2017) people living in poverty still do not generally own technologies commonly available to more affluent families, thus creating a cycle of usability deficit gaps: the less low socioeconomic populations have access to digital resources, the more difficulty they have achieving the same level of prowess in technology use demonstrated by more affluent families (Rowsell, Morrell, \& Alvermann, 2017). Jones (2013) described this phenomenon as normalized class-privilege. Even though technology onwership statistics are somewhat promising, as evidence by the three quarters of children in the United States with home access to cell phones (Rowsell, Morrell, \& Alvermann, 2017), the upward trend in access does not automatically equate to increased skills in the use of technology for productivity or learning. Students from low socioeconomic households as well as those living in rural settings, demonstrated lower levels of skills, utilization and access to technologies than students living in more affluent areas (Thomas, 2008). Kantabutra and Tang (2006) argued that rural students demonstrated decreased levels of academic performance due to differences in access, experience and use of technology in schools, while Rossing, Miller, Cecil and Stamper (2012) argued that students from lower socio-economic households had more than 50\% less experience with computers and mobile devices than affluent children in the same age group. Furthemore, Dijk (2006) argued that even if the gap of access to technology in the developed world seems to be closing, the gap in skills in the use of digital applications continues to widen. The implications of these trends should not be underestimated; the 21st century workforce must be equipped with specific hard skills, as well as soft skills, in order to competitively join a highly dynamic job market (Park Woolf, 
2010). Redefining the instructional experiences students learn through is essential to truly prepare the next generation of productive and highly adaptable workers; the shift will be crucial if current generations are to achieve readiness for a highly competitive real-world demanding the mastery of an updated set of skills (Park Woolf, 2010).

\section{Methods}

This systematic literature review was conducted utilizing the EBSCOhost, JSTOR, and LexisNexis databases. Articles published between January $1^{\text {st }}, 2002$ and November $30^{\text {th }}$ 2018 were considered for review based on the following criteria:

- Search terms: digital divide, and, technology and inequalities.

- Relevancy of topic: confronting the digital divide, one-to-one computing in lowincome schools, decreasing technology inequalities for college readiness, skills based digital divide, and technology integration and poverty.

- Qualitative and quantitative peer reviewed studies.

- Analzyed publications were not limited geographically, however, U.S. based research comprised the primary source of information.

Additionally, the following definitions were essential for the development of this review:

- Digital divide: gap in physical access to computers, and computers, the internet and mobile devices as technologies evolved (Deursen \& Dijk, 2010).

- Digital learning: high-quality instructional practice effectively utilizing technology to strengthen learning experiences while ensuring students reach their full potential (Alliance for Excellent Education, 2018).

- Technology skills: skills and competencies, beyond basic proficiency, allowing individuals to accomplish tasks in technology-rich environments (OECD, 2010a)

Information was obtained legally and cited following strict adherence to APA referencing format.

\section{Discussion - Conceptualizing the New Digital Divide}

The origins of research on the digital divide are based on statistics measuring population percentages lacking access to computers and network connections for a variety of purposes, including the ability to acquire information beyond physical reach. Unfortunately, access is still the most pervasive concept referred to when discussing the digital divide, mainly because access to devices, broadband networks and other technologies have driven the conceptualization of the argument for a long period of time (Dijk, 2006). However, according to Gunkel (2003) utilization, skills and abilities should be crucial elements 
surrounding discussions related to the digital divide, in particular when planning for technology-driven educational initiatives. KewalRamani et al. (2018) stated that U.S. students without access to the internet at home demonstrated lower levels of achievement in core subjects across national and international assessments. Camerini, Schulz and Jeannet (2017) argued that recent studies in Europe defined the digital divide in practical terms: children from parents with higher educational levels are more skilled at utilizing devices for informational needs. In a British study by Peters, Seeds, Goldstein and Coleman (2007), $92 \%$ of students reported having a computer with internet connectivity at home, however, access to the technology by social class differed from $97 \%$ of students (class $A B$ ) versus $69 \%$ of students (class E) (Figure 1) (Ferrer, Belvís \& Pàmies, 2011).

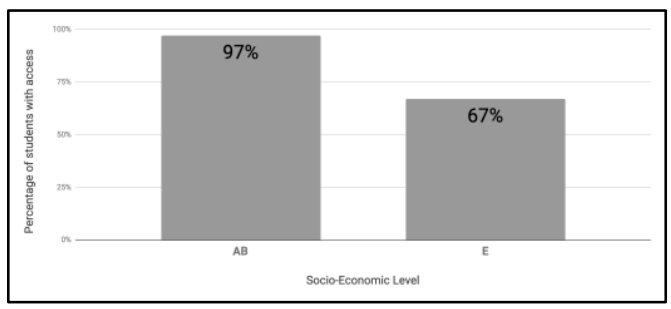

Figure 1. Internet connected device at home (adapted from "Tablet PCs, Academic Results and Educational Inequalities, ” by Ferrer, Belvís and Pàmies, 2011)

In the United States, students living below the poverty line between the ages of 5 and 17 , have lower rates of home internet access than students living between $100 \%$ and $185 \%$ of the poverty threshold (KewalRamani et al., 2018). There is also evidence of a gap in access based on race: American Indian/Alaska Native, Black, and Hispanic students have lower rates of internet home connectivity than their White, Asian, and of Two or More Races peers (KewalRamani et al., 2018). Additionally, despite the pervasive access to broadband internet connections in most American public-school classrooms, the digital divide based on instructional opportunities in low versus high socio-economic status schools remains a reality (Thieman \& Cevallos, 2017). Societal issues at the root of inequalities, including, professional status, ownership of assets, professional networks and access to power structures, may still be relevant when researching the cause of technology skill gaps. Unfortunately, a significant shortcoming of the digital divide research is the exclusion of the causes of inequalities in studies addressing technology skill gaps of low socio-economic populations (Dijk, 2006). Governments and planners in developing countries are increasingly wary and even alarmed at the width of the digital divide evidenced in lowincome populations: individuals who are being left behind due to low levels of access to technology, compounded by being left further behind by their more well-off fellow citizens due the disparate quality of their respective educational opportunities (Forestier, Grace \& 
Kenny, 2002). Plans can, and should be adopted, to challenge the notion of digital fault lines by ensuring all students, affluent and from poverty alike, have access to high quality learning through digital devices (Rowsell, Morrell, and Alvermann, 2017). There are encouraging signs that the concept of equity of access is taking hold in school systems across the United States. Keane and Keane (2017), argued that the availability of devices in classrooms based on 1:1 ratios is trending higher, while Zucker and Hug (2008) stated that the technology access barrier is vanishing: the number of American schools providing thousands of students with digital devices for instructional purposes continues to grow. Thomas and Lewis (2010) stated that as of 2008, $100 \%$ of U.S. public schools had at least one instructional computer with internet access while $58 \%$ of campuses owned laptop carts. Investing in learning technologies for integrating devices into instruction supports the commonly held belief that digital assets are beneficial for academic and career readiness (Lewis, 2016). However, merely providing devices is not enough; a fully developed strategic planning process for the integration of technology, executed with fidelity, is essential to achieve positive academic results (Williams \& Larwin, 2016). It is important to leverage digital tools in classrooms through robust pedagogy practices to effectively engage students on the reflective analysis of information, the creation of new knowledge and the distribution of digital content (Rowsell, Morrell, \& Alvermann, 2017). In order for these changes to take place, leading a paradigm shift requiring profound transformations in pedagogy practices, from teaching with technology, to intentionally guiding students to create and design through digital devices is necessary (Tan, Kim, \& Yeo, 2009). The development of writing skills in the digital age provides an excellent example; Jesson, Mcnaughton, Rosedale, Zhu and Cockle (2018) reported that writing instruction can change in classrooms with access to technology assets; a more comprehensive definition of writing in the digital classroom includes the use of images, sounds, and graphics, to support traditional written communication. The effective integration of learning technologies can also help to differentiate learning (Harris, Al-Bataineh, \& Al-Bataineh, 2016) and enhance digital collaborative interactions among students (Soffer \& Yaron, 2017).

\section{Current Challenges and Further Implications}

Cotten, Hale, Moroney, O’Neal and Borch (2011) argued that even though school systems across the United States are increasingly integrating technologies for learning, the lack of available data explaining the factors that determine the successful implementation of digital devices in classrooms is an issue. Understanding the local context, and more importantly, educators' needs, is crucial (Pruet, Ang and Farzin, 2016). Teachers are ultimately the ones driving the technology integration in classrooms, thus it is crucial to understand how and why educators accept to utilize mobile learning technologies as part of their instructional tool-kit (Ifenthaler \& Schweinbenz, 2013). The deployment of learning technologies 
requires specific strategies to address both, the digital integration skills of the teaching workforce, as well as systemic changes to support the success of the initiative (Stanhope, and Corn, 2014). Providing effective training and implementing organizational shifts to support the utilization of learning technologies in classrooms is, therefore, necessary; Keengwe, Schnellert and Mills (2011) argued that effectively integrating digital resources in classrooms is essential, if not critical, if schools are focused on engaging students effectively in the digital age while contributing to their college and career readiness status.

\section{Conclusion}

Beyond a definition based on access to technology assets, a more robust conceptualization of the digital divide has grown to include elements related to skills, competencies and abilities to utilize digital applications for learning, research, productivity and other meaningful purposes. Strategically planning to confront the digital divide in academic settings is an important aspect of educating the next generation of productive citizens. The importance of investing in digital assets for implementing effective learning experiences should not be underestimated; on the contrary, it should be considered essential and beneficial for student readiness. Even though providing access to learning technologies is an important first step, access by itself does not guarantee successful academic outcomes, or the narrowing of the digital divide. Strategies for the effective implementation of technologies for learning must include the planning of robust instructional application of the devices. The digital divide can be conceptualized as the absence of meaningful opportunities for students to be producers of information, as opposed to merely consumers of content, and to utilize technologies for learning, thus helping to narrow technology skill gaps based on income, access and opportunities. Ultimately, having the skills to utilize technology effectively to be productive and solve problems has been found to be increasingly important for the economic and social wellbeing of individuals (OECD 2016a). Providing meaningful digital learning opportunities to student populations is, therefore, not only our professional duty, but more importantly, a moral imperative.

\section{References}

Alliance For Excellent Education. (2018, February 22). About DLDAY. Retrieved April 15, 2018, from http://www.digitallearningday.org/about-dlday/

Camerini, A., Schulz, P. J., \& Jeannet, A. (2017). The social inequalities of Internet access, its use, and the impact on children's academic performance: Evidence from a longitudinal study in Switzerland. New Media \& Society, 20(7), 2489-2508. doi:10.1177/1461444817725918 
Cotten, S. R., Hale, T. M., Moroney, M. H., Oneal, L., \& Borch, C. (2011). Using affordable technology to decrease digital inequality. Information, Communication \& Society, 14(4), 424-444. doi:10.1080/1369118x.2011.559266

Deursen, A. V., \& Dijk, J. V. (2010). Internet skills and the digital divide. New Media \& Society, 13(6), 893-911. doi:10.1177/1461444810386774

Dijk, J. V. (2006). Digital divide research, achievements and shortcomings. Poetics, 34(45), 221-235. doi:10.1016/j.poetic.2006.05.004

Ferrer, F., Belvís, E., \& Pàmies, J. (2011). Tablet PCs, academic results and educational inequalities. Computers \& Education, 56(1), 280-288. doi:10.1016/j.compedu.2010.07.018

Forestier, E., Grace, J., \& Kenny, C. (2002). Can information and communication technologies be pro-poor? Telecommunications Policy, 26(11), 623-646. doi:10.1016/s0308-5961(02)00061-7

Gray, L., Thomas, N., \& Lewis, L. (2010). Teachers use of educational technology in U.S. public schools, 2009: First look. Washington, DC: National Center for Education Statistics, Institute of Education Sciences, U.S. Department of Education.

Gunkel, D. J. (2003). Second thoughts: toward a critique of the digital divide. New Media \& Society, 5(4), 499-522. doi:10.1177/146144480354003

Harris, J., Al-Bataineh, M., \& Al-Bataineh, A. (2016). One to one technology and its effect on student academic achievement and motivation. Contemporary Educational Technology, 7(4), 368-381.

Ifenthaler, D., \& Schweinbenz, V. (2013). The acceptance of Tablet-PCs in classroom instruction: The teachers' perspectives. Computers in Human Behavior, 29(3), 525-534. doi:10.1016/j.chb.2012.11.004

Jesson, R., Mcnaughton, S., Rosedale, N., Zhu, T., \& Cockle, V. (2018). A mixed-methods study to identify effective practices in the teaching of writing in a digital learning environment in low income schools. Computers \& Education, 119, 14-30. doi:10.1016/j.compedu.2017.12.005

Jones, Stephanie. "Critical Literacies in the Making: Social class and identities in the early reading classroom." Journal of Early Childhood Literacy, vol. 13, no. 2, 2013, pp. 197224., doi:10.1177/1468798411430102.

Kantabutra, S., \& Tang, J. C. (2006). Urban-rural and size effects on school efficiency: the

case of northern thailand. Leadership and Policy in Schools, 5(4), 355-377. doi:10.1080/15700760600968416

Keane, T., \& Keane, W. (2017). Achievements and challenges: Implementing a 1:1 program in a secondary school. Education and Information Technologies, 22(3), 1025 1041. doi:10.1007/s10639-016-9470-4

Keengwe, J., Schnellert, G., \& Mills, C. (2011). Laptop initiative: Impact on instructional technology integration and student learning. Education and Information Technologies, 17(2), 137-146. doi:10.1007/s10639-010-9150-8

KewalRamani, A., Zhang, J., Wang, X., Rathbun, A., Corcoran, L., Diliberti, M., and Zhang, J. (2018). Student access to digital learning resources outside of the classroom (NCES 2017-098). U.S. Department of Education. Washington, DC: National Center for Education Statistics. 
Lewis, M. (2016). Professional learning facilitators in 1:1 program implementation: technology coaches or school librarians? School Libraries Worldwide, 22(2), 13-23A. doi:http://libproxy.library.unt.edu:2126/10.14265.22.2.02

Organization for Economic Cooperation and Development [OECD]. (2010a). The OECD programme for the international assessment of adult competencies (PIAAC). Competencies in technology-rich environments. Paris: OECD.

Organization for Economic Cooperation and Development [OECD]. (2016a). Skills matter: further results from the survey of adult skills. Paris, OECD.

Park Woolf, B. (2010). A roadmap for education technology. Retrieved from https://cra.org/ccc/wp-content/uploads/sites/2/2015/08/GROE-Roadmap-for-EducationTechnology-Final-Report.pdf

Peters, M., Seeds, K., Goldstein, A., \& Coleman, N. (2007). Parental involvement in children's education 2007. BMRB Social Research,1-148.

Pruet, P., Ang, C. S., \& Farzin, D. (2016). Understanding tablet computer usage among primary school students in underdeveloped areas: Students' technology experience, learning styles and attitudes. Computers in Human Behavior,55, 1131-1144. doi:10.1016/j.chb.2014.09.063

Rossing, J., Miller, W., Cecil, A., \& Stamper, S. (2012). ILearning: the future of higher education? Student perceptions on learning with mobile tablets. Journal of the Scholarship of Teaching and Learning, 12(2), 1-26.

Rowsell, J., Morrell, E., \& Alvermann, D. E. (2017). Confronting the digital divide: debunking brave new world discourses. The Reading Teacher, 71(2), 157-165. doi:10.1002/trtr.1603

Stanhope, D. S., \& Corn, J. O. (2014). Acquiring teacher commitment to 1:1 initiatives: the role of the technology facilitator. Journal of Research on Technology in Education, 46(3), 252-276. doi:10.1080/15391523.2014.888271

Soffer, T., \& Yaron, E. (2017). Perceived learning and students' perceptions toward using tablets for learning: the mediating role of perceived engagement among high school students. Journal of Educational Computing Research,55(7), 951-973. doi:10.1177/0735633117689892

Tan, S., Kim, B., \& Yeo, J. (2009). Learning with technology: learner voice and agency. Educational Media and Technology Yearbook,117-133. doi:10.1007/978-1-4419-15160_8

Thieman, G. Y., \& Cevallos, T. (2017). Promoting educational opportunity and achievement through 1:1 iPads. International Journal of Information and Learning Technology, 34(5), 409-427. doi:10.1108/ijilt-06-2017-0047

Thomas, D. (2008). The Digital Divide: What schools in low socioeconomic areas must teach. The Delta Kappa Gamma Bulletin, 74(4), 12-17.

Williams, N. L., \& Larwin, K. H. (2016). One-to-one computing and student achievement in ohio high schools. Journal of Research on Technology in Education, 48(3), 143-158. doi:10.1080/15391523.2016.1175857

Zucker, A. A., \& Hug, S. T. (2008). Teaching and learning physics in a 1:1 laptop school. Journal of Science Education and Technology, 17(6), 586-594. doi:10.1007/s10956008-9125-3 